\title{
Multi - habitation: A form of Housing in African Urban Environments
}

\author{
OKEYINKA Yetunde \\ Department of Architecture, Ladoke Akintola University of Technology, Ogbomosho, Nigeria
}

\begin{abstract}
The study examined the phenomenon of multi-habitation as a form of housing in the African urban environments using Ogbomosho a pre-colonial city situated in south-western part of Nigeria as a case study. Multi-habitation is a concept describing a social situation within a space. In multi-habitation people negotiate over limited space where extended family occupancy or multi-family occupancy is common. The study also compared multi-habitation in the traditional African culture, how it functions in the African environments settings and why multi-habitation is still functioning in the African Urban Environments, despite the fact that the official attitude is not positive about this living condition.

Analysis of multi- habited houses studied during a survey of House type conducted in 2007 formed the basis for this study as it revealed that 74\% of the total numbers of Houses in Ogbomosho were rooming and family compounds where multi- habitation was practiced. The study revealed that increasing multi - habitation is synonymous with increasing urbanization and poverty.
\end{abstract}

Keywords: Multi-habitation, Rooming House, Family Compounds, House-form, and Poverty.

\section{Introduction}

Multi-habitation is a concept describing a social situation within a space (Schlyter, 2003). It can be described in terms of sharing facilities in a dwelling with extended family occupancy or multi-family occupancy which is common in many parts of the third world (Korboe, 1992, Tipple, 2000). Graham Tipple who primarily had West African compound houses in mind coined the concept, (Tipple, 2000). The house form in which multihabitation is practiced is a rooming house whereby the building is divided into separate rooms. This house form is distinguishable by an organization which allows different households/families to live in full view of one another in a relatively small space. This house-form represents the more traditional lifestyle in West Africa which also represents in a physical entity the power and cohesion of the extended family system, which is one of the many features that have survived in West Africa. In the traditional African settings, the need for large number of rooms to accommodate the extended family is a major driving force for the growth of multihabitation.

Schlyter 2003, Tipple et al 1999, all affirmed that the traditional compound in West Africa has most of its rooms opening onto a central courtyard and in it, anywhere between 20 and 200 people who do not consider themselves as one household share a living space in a situation referred to as multi-habitation. Also, the Brazilian house type, a non-compound house with rooms aligned along a central corridor is another type of house-form which encourages multi-habitation.

This type with rooms on both sides of an access corridor is generally called "face $-m e-I-$ face - you" in the local parlance in Nigeria because the doors to the rooms of opposite sides of the corridor often face one another.

Those traditional compounds and the Brazilian non-compound rooming house have become a dominant house form and house type for the large population and immigrant population in the rapidly expanding cities in African nations (Tade, 1989). In the traditional African settings, the compound house is common and was and is still a shared property. Many generations often inhabit it and several layers of blood and marriage Kith and kin's, and utilities are shared among all residents. In compound houses, behavior is regulated by commonly held customs and practices to which all who live in the house subscribe. Although there are compound houses in cities of developing countries till date, the traditional housing system has been transposed into a non-traditional urban settings and strangers now rent rooms in family dominated compounds (Korboe, 1992), as it is believed to be a way of coping or dealing with poverty and the struggle to meet accommodation need in the urban environments of West African countries. Tipple (2004) concluded that multi - habited form allows inexpensive accommodation and provided many of the advantages of collectivist life for residents.

From a survey of house-type conducted in Ogbomosho in 2007 the traditional compound was the most common house-type in Ogbomosho, while the Brazilian house-type that is, the face - me - I-face you was the second most common house type; these are house types occupied by multi family. See table 1.0 for distribution of houses by type in Ogbomosho. Although to be living in multi-habitation in these houses is to live quite differently from the idealized official view of the happy single family home; these houses are preponderant 
because the urban population continues to expand very quickly, the overwhelming majority are poor, and public housing accounted for small share of the housing stock in developing countries of Sub-Saharan Africa (Vlient 1987, Gilbert, 2000). This study therefore analyzed the house form of traditional courtyard compound and rooming houses, how it functioned in the traditional setting, and why it is still functioning in the present urban settings,

Table 1.0: Distribution of Houses by Type in Ogbomosho.

\begin{tabular}{|c|l|c|c|}
\hline S/No. & \multicolumn{1}{|c|}{ House Type } & \multicolumn{1}{|c|}{ Frequency } & Percentage \\
\hline 1. & Family House & 161 & 40.25 \\
\hline 2. & Single House on one lot occupied by one family & 52 & 13 \\
\hline 3. & $\begin{array}{l}\text { Apartment in a building with more than one } \\
\text { apartment }\end{array}$ & 45 & 11.25 \\
\hline 4. & Duplex & 5 & 1.25 \\
\hline 5. & $\begin{array}{l}\text { Rooming house (face-me-I-face-you) occupied by } \\
\text { more than one family }\end{array}$ & 137 & 34.25 \\
\hline & Total & 400 & 100 \\
\hline
\end{tabular}

\section{Source: Authors Survey 2007}

\section{House-form of Compound and Rooming Houses}

- $\quad$ Built environment refers to the human-made surroundings that provide the setting for human activity, ranging in scale from buildings and parks.

\subsection{Traditional Courtyard Compound House}

The traditional Courtyard compound house form represents the more traditional lifestyle in West Africa and Yoruba cities. it is associated with the extended family and by implications with the indigenous form of housing. The need for large number of rooms to accommodate the extended families is a major determinant of this house form. A dominant feature of the compound house is the central courtyard. Courtyard provides a climatically open air environment, and it is particularly suitable for mutual care and a communal lifestyle useful for meetings for which family houses are renowned. A typical compound consists of groups of rooms ranged around one or more courtyards or impluvia and with verandah overlooking the courtyard. Tipple et al, (1999) affirmed that the traditional compound in West Africa has most of its rooms opening into a central courtyard and in it anywhere between 20 and 200 people who do not consider themselves as one household share a living space in a situation referred to as multi - habitation. The compound house has long been providing accommodation required by low-income households in West African cities, citing Kumasi in Ghana as an example.

Tipple et al (1997), also confirmed that as the urban population of sub-Saharan African continued to grow rapidly, formal housing supply remained incapable of providing for their needs, and as a result, very large number of households could not afford to own or rent a "decent" or "adequate" single household dwelling. The conclusion among indigenous scholars of courtyard compound houses is that it is a traditional house form in which people living in poverty can find accommodation that suits their budgets and which provide some cultural, social and economic support for their sojourn in the city.

The house form encourages extended families or individual households who are not members or families linked to the extended families at all, to rent rooms or suites of rooms in compound houses in West African cities.

Compound houses are widespread in West Africa and have been for so for ages. Although the stock of compound houses has ceased to grow, it is still providing accommodation to the majority of the low - income population in developing cities particularly in Ghana and Nigeria.

A recent study in Ogbomosho, a city in Oyo state of Nigeria documented the distribution of house types in Ogbomosho. The study concluded that the compound house is the most common house type especially in the central core and the central business district areas; (Okeyinka, 2007). See figure 2.1, for a typical floor plan of a compound house, 'ile Abese Olowe' in Ogbomosho. Also, the data collected in a study by Okeyinka and Ayinla (2013) documented occupancy rates in the compound and rooming houses as 4.6 per room, despite the disadvantages of these house types. It also revealed that majority of the low- income group; those who belonged to the lower echelon of education still preferred accommodation in compound and the Brazilian housetype. Although the Western style nuclear family household or villa type house is seen as an ideal, multi habited compound and Brazilian face - me - I-face - you house types are very common in cities of developing countries. 
Fig 2.1: Plan of Typical Compound House in Ogbomosho, a City in Oyo state Nigeria (2007).

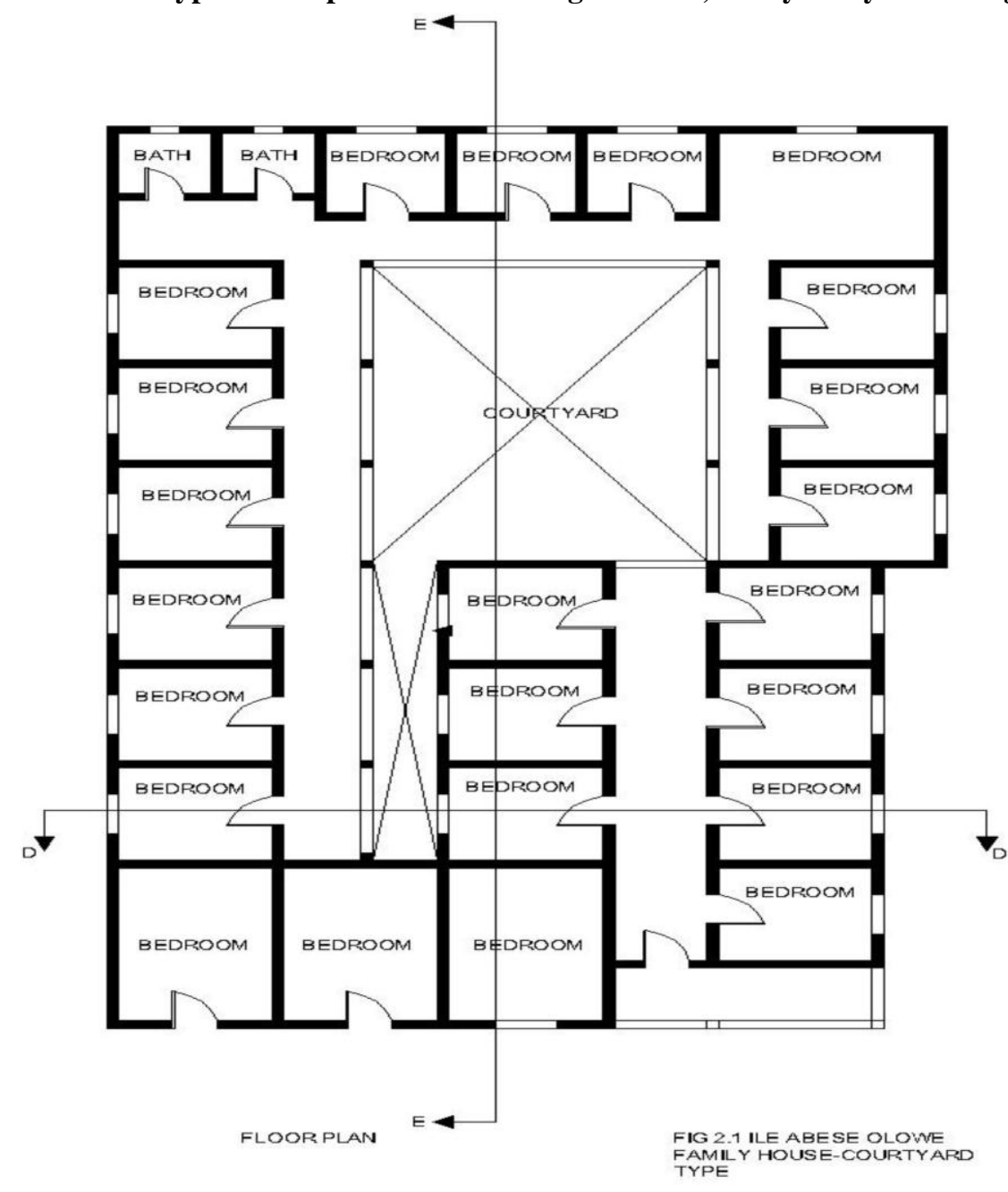

\subsection{Rooming House/ Face me- i- face-you.}

The Brazilian House type or face - me - I-face you as is generally referred to in the Nigerian parlance is a rooming house. It consists of a set of rooms arranged along and opening off

a central hall. The hall serves an important function in the running of the house and provides space for working and storage as well.

The back of the house generally contains a kitchen, latrine and general service area, but in houses where the central hall is narrow, there will be a rear courtyard where many of the hall's functions are carried out. See figure 2.2 for a typical floor plan of a rooming house, 'ile Adonis' a rooming house in Ogbomosho.

This rooming house or face me I face you was the second form or a new type of family house which became prominent during the 1930's when earnings from cocoa, palm oil etc allowed a young man who inherited a share in the family compound to establish his own house into which some of the family members moved with him (Amole et al, 1993). During this period new building practices and building materials were introduced as a result of industrial revolution and the influx of freed slaves into West Africa (Marafato, 1983). Ever since then, this house type has been supplying accommodation in the face of acute housing shortages in developing countries, Nigeria inclusive. Expert meeting Stockholm ERSO (2008) concluded with these facts about housing in Nigeria; that 2006 census estimates Nigerian population at 140 million; that $30 \%-40 \%$ of the total population live in the urban areas, with an average household of 5 persons, that the occupancy ratio of houses in Nigeria is 6 persons per room of $20 \mathrm{~m}^{2}$, and that residential house ownership in Nigeria is less than $25 \%$, compared with $75 \%$ international benchmarks.

The form of this house type encourages multi - habitation where by different households rent a room or suite of rooms depending on their financial capability. Each room functions independently on its own and it's only the basic services that are shared. This house type has become a residential property where rooms are available for rent to people, the owner is the landlord and can enter the common areas such as the lobby without 
giving any notice and may also be living in the house. A survey of house type conducted in 2007 in Ogbomosho revealed that, rooming house is the second most common house type in the city; this confirms that apart from the fact that multi-habitation has been a traditional way of living among the traditional African people, it is still practiced among many residents in cities of developing countries.

Fig 2.2: Plan of a Typical Rooming House/Face - me - I - face you in Ogbomosho, a city in

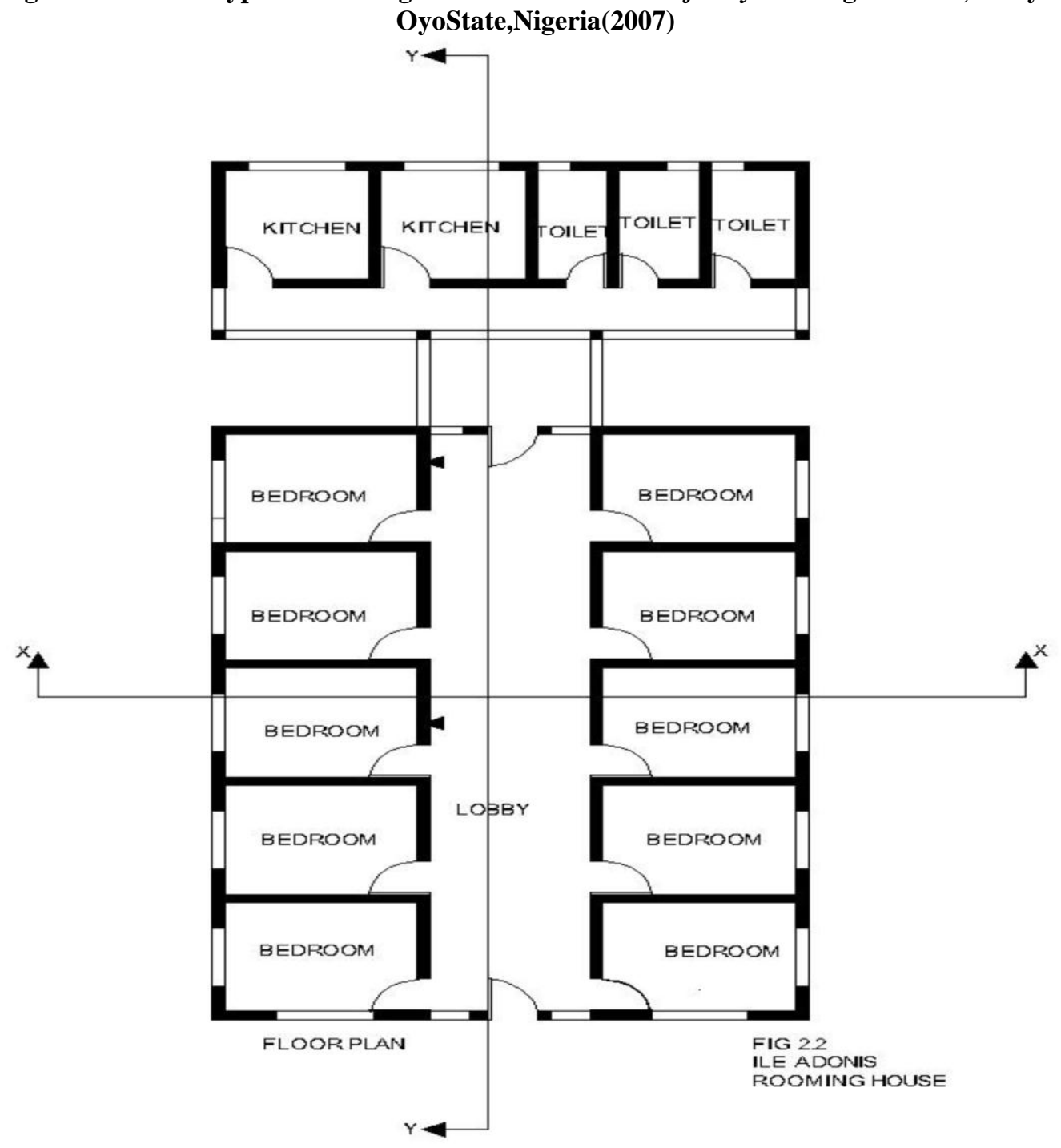

III. Why Multi - habitation is still functioning in African Urban Environments

Olokesusi et al, (2003) asserted that many of the low-income households

in the urban areas are hit by poverty and cannot afford adequate housing therefore they rent room or rooms in multi-habited houses. As a result of poverty also, a high proportion of the tenants occupy a single room in rooming or courtyard houses, he concluded that the high level of overcrowding a

represented by the high households and room densities is mainly a function of poverty. It can be concluded therefore that poverty is one of the reasons why multi-habitation is still very prevalent in cities of developing countries, as the low earning power of the majority manifests especially in lack of funds to procure housing.

Recent studies show a high population and urbanization in Asia and African cities, which also translate to a high demand for housing in these cities (Crux, 2008). Resources devoted to housing have become strained in these cities. The inadequate supply of housing in the regions can be seen in the high house - price - to income ratio and high share of slum dwellers and those in multi-habitation among the urban populations.

One can conclude therefore that, in developing countries where poor people have had severe difficulties in affordable housing, majority have become tenants and several households live in houses with many rooms either in family houses, tenements buildings or in rooming houses adopting a system of multihabitation. 
Gilbert (2000) and Grooves (2004) confirmed that majority of residents in cities of developing countries were renters, that a large proportion of households were crowded into a single room in a building which had many other tenants and which was not regularly maintained; and where facilities and services were a long way from what an ideal house in the developed countries looked like. Rakodi (1995) also noted that a high proportion of the tenants in these cities occupied a single room in rooming or courtyard houses, and that the poor were predominantly renters, who by virtue of their income and limited availability of housing finance had to take to renting. Hence, it is obvious that multi-habitation has persisted in African cities because majority of the poor see it as a credible alternative to other forms and as a form of cheap rental housing.

\section{Conclusion}

Multi-habitation is a concept describing a social situation within a space. It can also be described in terms of sharing facilities in a dwelling among extended family or where multi-family live together under the same roof. In multi-habitation, people negotiate over limited space, and extended or multi-family occupancy is common. This concept was coined by Graham Tipple who primarily had West African compound houses in mind.

In traditional African settings, the compound house is common and multi - habitation is common too. Many generations often inhabit the compound house and several layers of blood related relatives share utilities among themselves. Behavior is regulated by commonly held customs and practices to which all who live in the house subscribe.

There are compound houses in some of our cities till date, but the traditional housing system has been transposed onto non-traditional urban settings, where non - relative now rent rooms in family compounds, this is believed to be a way of dealing with poverty and the struggle for survival in urban environments of developing countries.

Multi-habitation thrives in the traditional African environments and is still prevalent in the urban African environments due to the preponderance of the house-forms in both the courtyard compounds and rooming houses. This is because the multi-habited house form allows inexpensive accommodation and many of the advantages of collectivist life for the residents. Although to live in multi habitation is to live quite differently from the idealized official view of the happy single family house. Literature has shown that in reality, poverty, rate of urbanization and housing affordability have forced both urban low-income and the poor to negotiate and adapt to the use of limited space in multi-habitation.

\section{References}

[1]. Amole, B. Korboe D and Tipple, G. (1993): The family - house in West Africa: A forgotten Resource for Policy Maker? Third World Planning Review 15/4

[2]. ERSO (2008), Export Meeting Stockholm, Pages 21-22.

[3]. Gilbert, A (2000): Housing in third world cities "The critical issues" Geographical AssociationGeography Vol.85, No.2

[4]. Grooves, R. (2004): "Challenges Facing the Provision of Affordable Housing in African cities". Housing Finance International, Vol.18, No.4

[5]. Korboe, D (1992): “Multi-habitation: An Analysis of Residence in a West African City" Open House International Vol.17 No.1

[6]. Marafato, M. (1983): "Nigerian Brazilian Houses", Istituto Italiano dicultura, Lagos.

[7]. Okeyinka Y.R (2007): "House types and the meaning of House in Ogbomoso". M.Phil Thesis, Obafemi Awolowo University, Ile Ife

[8]. Okeyinka Y. R and Ayinla A. K (2013): "Household size and Housing characteristics of some House types in Ogbomosho" Book of Reading, Urban Design and Sustainability II.Department of Architecture, FUTA Akure.

[9]. Olokesusi, F. Agunbiade F. Ogbuzobe J.E. and Adeagbo D. (2003): "Housing perspective of Poverty in Nigeria. In Poverty in Nigeria: A multi-dimensional perspectives" (eds) D. Olu Ajakaiye and Ade.S. Olumola. Nigeria Institute of Social and Economic Research (NISER) Ibadan

[10]. Prince Christian R. Cruz (2008): "Transaction costs and Housing Affordability in Asia" International Real Estate Review, Vol.11, No.1 Pp 128-150.

[11]. Rakodi, C. (1995): "Rental Tenure in the cities of Developing Countries" Urban Studies, 32, 91

[12]. Schlyter, A (2003): "Multihabitation Urban Housing and Everyday life in Chitungqiza Zimbabwe" Research Report No 123, Nordic African Institute, Uppsala.

[13]. Tade, A.A. (1989): "Many routes enter the market place" Housing submarkets for the urban poor in Metropolitan Lagos, Nigeria", Environments and Urbanization, Vol 1, No 2.

[14]. Tipple, A. Graham (2000); “Extending themselves: User Limited Transformations of Government Built Housing in Developing Countries" Liverpool University Press Liverpool.

[15]. Tipple, A.G; Korboe, D; Wills, K and Garrod: G. (1999): Housing supply in Ghana: $\quad$ A study of Accra Kumasi and Berekum" Progress in Planning, 51 Number 4.

[16]. Tipple, A. Graham, Owusu, Stephen. Pritchard, Clumbus (2004): “User-Initiated Extensions inGovernment-Built Estates in Ghana and Zimbabwe: Unconventional but effective Housing supply” Africa Today, Volume 51, number 2.

[17]. Tipple,A .G, D. Korboe and G. Garrod (1997): "Income and Wealth in House Ownership studiesin Urban Ghana" Housing Studies 12 (1).

[18]. Van Vlient W, (1987): Housing in the third world Environment and behavior, Vol.19, No. 3 Sage Publications 